\title{
Teaching Video NeuroImages: Inverted Beevor sign in facioscapulohumeral muscular dystrophy
}

\author{
Constantinos Papadopoulos, MD, PhD, Sofia Xirou, MD, PhD, Evangelia Kararizou, MD, PhD, and \\ George K. Papadimas, MD, PhD
}

Neurology ${ }^{\circledR}$ 2020;95:e2714. doi:10.1212/WNL.0000000000010646

A 50-year-old man with facioscapulohumeral muscular dystrophy 1 (FSHD1), scapuloperoneal weakness, and bilateral scapular winging presents a downward movement of his umbilicus while attempting to get up from the recumbent position (video 1). Beevor sign, an upward umbilicus deviation when the supine patient is flexing the neck or tries to sit up without the use of the hands, indicates lower abdominal muscle weakness. It is highly sensitive and specific, but not diagnostic, for FSHD1, because it is described in other myopathies. ${ }^{1,2}$ Beevor sign may be present in this "inverted" form, indicating predominant weakness of upper rectus abdominis muscle.

\section{Study funding}

No targeted funding reported.

\section{Disclosure}

The authors report no disclosures relevant to the manuscript. Go to Neurology.org/N for full disclosures.

Appendix Authors

\begin{tabular}{lll}
\hline Name & Location & Contribution \\
\hline $\begin{array}{l}\text { Constantinos } \\
\text { Papadopoulos, } \\
\text { MD, PhD }\end{array}$ & $\begin{array}{l}\text { First Department of Neurology, Eginition Hospital, } \\
\text { Medical School, National and Kapodistrian University } \\
\text { of Athens, Greece }\end{array}$ & $\begin{array}{l}\text { Design of the study, analysis and } \\
\text { interpretation of the data, drafting } \\
\text { manuscript, multimedia files } \\
\text { creation }\end{array}$ \\
$\begin{array}{l}\text { Sofia Xirou, MD, } \\
\text { PhD }\end{array}$ & $\begin{array}{l}\text { First Department of Neurology, Eginition Hospital, } \\
\text { Medical School, National and Kapodistrian University } \\
\text { of Athens, Greece }\end{array}$ & $\begin{array}{l}\text { Analysis and interpretation of the } \\
\text { data, revising the manuscript }\end{array}$ \\
$\begin{array}{l}\text { Evangelia } \\
\text { Kararizou, MD, } \\
\text { PhD }\end{array}$ & $\begin{array}{l}\text { First Department of Neurology, Eginition Hospital, } \\
\text { Medical School, National and Kapodistrian University } \\
\text { of Athens, Greece }\end{array}$ & $\begin{array}{l}\text { Analysis and interpretation of the } \\
\text { data, revising the manuscript }\end{array}$ \\
$\begin{array}{l}\text { George K. } \\
\text { Papadimas, MD, } \\
\text { PhD }\end{array}$ & $\begin{array}{l}\text { First Department of Neurology, Eginition Hospital, } \\
\text { Medical School, National and Kapodistrian University } \\
\text { of Athens, Greece }\end{array}$ & $\begin{array}{l}\text { Analysis and interpretation of the } \\
\text { data, revising the manuscript }\end{array}$ \\
\hline
\end{tabular}

\section{References}

1. Althagafi A, Nadi M. Beevor sign. Treasure Island, FL: StatPearls; 2020. Available at: ncbi.nlm.nih.gov/books/NBK545262/.

2. Eger K, Jordan B, Habermann S, Zierz S. Beevor's sign in facioscapulohumeral muscular dystrophy: an old sign with new implications. J Neurol 2010;257:436-438.

\author{
Correspondence \\ Dr. Papadopoulos \\ constantinos \\ papadopoulos@yahoo.com
}

\section{MORE ONLINE}

\section{- Video}

$\rightarrow$ Teaching slides

links.lww.com/WNL/

B188 


\section{Neurology}

\section{Teaching Video NeuroImages: Inverted Beevor sign in facioscapulohumeral muscular dystrophy}

Constantinos Papadopoulos, Sofia Xirou, Evangelia Kararizou, et al. Neurology 2020;95;e2714 Published Online before print August 14, 2020

DOI 10.1212/WNL.0000000000010646

This information is current as of August 14, 2020

Updated Information \& Services

References

Subspecialty Collections

Permissions \& Licensing

Reprints including high resolution figures, can be found at: http://n.neurology.org/content/95/19/e2714.full

This article cites 1 articles, 0 of which you can access for free at: http://n.neurology.org/content/95/19/e2714.full\#ref-list-1

This article, along with others on similar topics, appears in the following collection(s):

All Clinical Neurology

http://n.neurology.org/cgi/collection/all_clinical_neurology Muscle disease

http://n.neurology.org/cgi/collection/muscle_disease

Information about reproducing this article in parts (figures,tables) or in its entirety can be found online at:

http://www.neurology.org/about/about_the_journal\#permissions

Information about ordering reprints can be found online:

http://n.neurology.org/subscribers/advertise

Neurology ${ }^{\circledR}$ is the official journal of the American Academy of Neurology. Published continuously since 1951, it is now a weekly with 48 issues per year. Copyright (C 2020 American Academy of Neurology. All rights reserved. Print ISSN: 0028-3878. Online ISSN: 1526-632X.

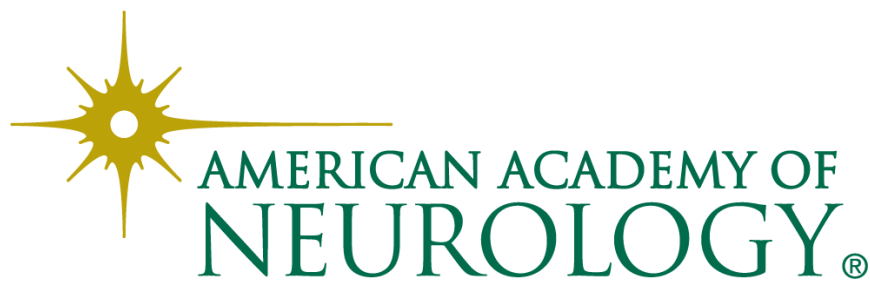

